Article

\title{
A Geographical Information Approach for Forest Maintenance Operations with Emphasis on the Drainage Infrastructure and Culverts
}

\author{
Apostolos Kantartzis ${ }^{1, *}$, Chrisovalantis Malesios ${ }^{2}\left(\mathbb{D}\right.$, Anastasia Stergiadou ${ }^{3} \mathbb{D}$, Nikolas Theofanous ${ }^{4}$, \\ Stergios Tampekis ${ }^{5}$ (D) and Garyfallos Arabatzis ${ }^{1}$
}

\section{check for} updates

Citation: Kantartzis, A.; Malesios, C.; Stergiadou, A.; Theofanous, N.;

Tampekis, S.; Arabatzis, G. A Geographical Information Approach for Forest Maintenance Operations with Emphasis on the Drainage Infrastructure and Culverts. Water 2021, 13, 1408. https://doi.org/ 10.3390/w13101408

Academic Editor:

Dimitrios Myronidis

Received: 1 April 2021

Accepted: 15 May 2021

Published: 18 May 2021

Publisher's Note: MDPI stays neutral with regard to jurisdictional claims in published maps and institutional affiliations.

Copyright: (c) 2021 by the authors. Licensee MDPI, Basel, Switzerland. This article is an open access article distributed under the terms and conditions of the Creative Commons Attribution (CC BY) license (https:/ / creativecommons.org/licenses/by/ $4.0 /)$.
1 Department of Forestry and Management of the Environment and Natural Resources, Democritus University of Thrace, 193 Pantazidou St., 68200 Orestiada, Greece; garamp@fmenr.duth.gr

2 Department of Agricultural Economics and Rural Development, Agricultural University of Athens, 75 Iera odos St., 11855 Athens, Greece; malesios@aua.gr

3 Department of Forestry and Natural Environment, Aristotle University of Thessaloniki, 54124 Thessaloniki, Greece; nanty@for.auth.gr

4 Department of Environmental Sciences, Wageningen University \& Research, Droevendaalsesteeg 3, 6708 PB Wageningen, The Netherlands; nikolas.theofanous@wur.nl

5 Region of Epirus, Governor's Office, 45221 Ioannina, Greece; stampeki@gmail.com

* Correspondence: apkantar@fmenr.duth.gr

Abstract: Forest operations engineering deals with all the essential infrastructure operations aiming at the efficient management of forested areas, which constitutes a prerequisite for the development of mountainous economies. Thus, the need for addressing this objective in an effective way, in conjunction with other issues associated with the protection and preservation of forest wealth, is of utmost importance. There are a whole range of forest operations for which a decision-making webtool can potentially be utilized. This paper introduces an online decision-making tool for managing forest roads, which uses information derived from rainfall-runoff simulation. The proposed tool can be used to provide information about forest works maintenance and damage prevention in a forest environment. Furthermore, the tool assists in visualizing forest operations and achieves the optimization of their management. The development of the decision-making tool is also described, and a real case study (the Koupa watershed) is presented in detail to demonstrate its application and resulting advantages. The rainfall-runoff simulation was conducted for ten sub-basins in order to evaluate the efficiency of the corresponding culverts in the Koupa watershed.

Keywords: forest operations engineering and management; web-platform; maintenance operations; decision making; GIS; HEC-GeoHMS; HEC-HMS

\section{Introduction}

Forest operations in general are not only engineering activities but also ecological actions that require planning and analysis, like other management activities do, for instance, timber harvesting, wildlife management, and so forth [1,2]. Forest operations engineering encompasses essential infrastructure projects for the development of mountainous (and subsequently national) economies, and thus the need for addressing the latter objective in an effective way, in conjunction with other problems associated with the protection and preservation of forest wealth is of great importance [3-5]. Forest infrastructures in general, and road infrastructures in particular, play a key role in forest organization; forest utilization; and transportation of products, services, and maintenance [6]. Forest roads are an essential yet costly part of forest management, hence optimization methods are significant tools in the planning of road systems [7]. In practice, addressing forest operations in an effective way is not straightforward [8]. The main obstacles in fulfilling these tasks include issues such as the lack of centralized 
recording of forest operations (e.g., through the use of a maintenance history website) or the inadequate scheduling of regular maintenance.

There is a continuous need for careful attention to regular monitoring and maintenance of forest infrastructures and roads to ensure forest sustainability. Thus, it is evident that forest road network planning plays a crucial role in fulfilling the goals of sustainable forest management [7]. Issues such as gravel thickness, density, gradient, cross-slope, distance between culverts, diameter of culverts, appropriate depth, and width of ditches can prevent the adverse effects of road degradation, which can lead to dramatic increases in maintenance costs. Sediment accumulation at culverts is another major problem with direct consequences, such as causing water crossing failures and roadway overtopping during flood events $[9,10]$. For instance, in the USA, the increasing intensity and frequency of precipitation in recent years combined with human interventions [11] has drastically increased the natural water regimes and sediment transport in watersheds [12-14].

Hence, a unified approach to constructing and maintaining forest infrastructures and forest roads is required and is essential to achieve optimization of resources and the proper management of forest operations. Low volume forest roads planning can be a driving force for the development of a forested area, especially when it is of high tourist interest [15]. By utilizing modern technologies such as orthophotomaps, digital terrain models, and land use cartographic maps or classes, one is able to develop different forest applications using GISs (Geographic Information Systems) [16]. Research on Web-based geovisual applications that improve the understanding of complex environmental processes with emphasis on forest roads and culverts management is still rare in the forest operations and forest management sector, except for a few studies $[8,14,17,18]$.

The present study contributes to the development of a decision-making platform for the management of forest operations. To the best of our knowledge, there are very few attempts and proposals for globally adoptable web tools and platforms for decision making that may assist in the management of forest operations in a holistic way. The problem of ungauged small basins negatively affects the management of forest operations. Adequate hydrological data are required in order to define an efficient and suitable course of action.

This paper introduces an online decision-making platform for managing forest operations that uses information derived from rainfall-runoff simulation. In particular, a decision-making web-tool is proposed based upon simulating the spatial and temporal allocation of rainfall-runoff processes within a specific forest region. The rainfall-runoff process in a specific region of interest is generated by a geospatial analysis of forest basins using GIS-based software. Specifically, the geospatial analysis of the forest basins is performed using HEC-GeoHMS software. The HEC-GeoHMS is an extension of ArcGIS software and was developed by the Hydrologic Engineering Center (HEC) in collaboration with the Environmental Systems Research Institute (ESRI) Corporation. HEC-GeoHMS has been elaborated as a toolkit that enables the stakeholders to perform spatial analysis by developing hydrologic parameters. This software is a widely used extension of Geographic Information Systems (GIS) [19-22]. The output hydrologic parameters generated by HECGeoHMS constitute the input data for the rainfall-runoff simulation model. The fact that the HEC-GeoHMS is applicable to small ungauged basins [22] and complex areas [20], as well as to a wide range of geographic areas [23], and can easily be coupled with hydrologic simulation models, determines the appropriateness of the software in this research.

Watershed delineation and the calculation of the hydrologic parameters are considered as the starting points throughout the rainfall-runoff simulation process. The hydrological modeling is performed using the HEC-HMS software. The HEC-HMS has been developed by the U.S. Army Corps of Engineers of the Hydrologic Engineering Center (HEC) and enables the stakeholders to simulate the precipitation-runoff processes in dendritic basins [24]. The HEC-HMS software is widely used [25-28] and is capable of simulating the rainfall-runoff processes in various geographic areas [24]. It is applicable in both natural and controlled basins [21] and can be applied in local and regional scale watersheds [21]. This model enables the stakeholders to calculate the infiltration and surface runoff using 
miscellaneous loss and transform methods. In this study, we used the soil conservation service curve number (SCS CN) and the soil conservation service (SCS) unit hydrograph method as loss and transform methods, respectively. Due to the lack of reliable meteorological data, the Gumbel distribution was applied with a return period of 25 years. The structural dimensions of the forest culverts were defined by the maximum flood discharge in 25-year flow. The main advantages of the HEC-HMS are higher accessibility and efficiency compared to other models.

Among the main goals of the present study and proposed tool are the updating of spatial and descriptive data of forest operations and their preliminary maintenance programming, the reduction of the likelihood of damage from natural disasters due to the bad state of repair of the existing infrastructures, and finally the reduction of maintenance costs through scheduled tasks. There are many social groups that can be benefited from the utilization of the proposed tool, including woodland populations, farmers, foresters, hunters, and firefighters.

The tool developed and proposed in the current research provides information about the operations' planning and management (e.g., reducing vulnerability of roads to environmental damage) in the forest environment. This is achieved by the proposed methodology, which serves as a database, combining geospatial data with historical reported events, for the handling and identification of critical issues in the forest infrastructure. In addition, the platform provides visualization of the technical projects and achieves the optimization of their management, by using suitable algorithms.

This application can support the following technical projects: "retaining workssupporting works", "side ditch" and "drainage system". By using the platform, any forest service officer or visitor, while browsing and utilizing the proposed web platform, can report any problem (in a list of 6 possible options, including small surface damage, circumferential crack, longitudinal or multiple cracking, loss of level, multiple fractures and deformation, and collapsed-blocked) in a technical project, thereby creating a real-time database. Thus, in addition to estimating streamflow, the platform creates a dynamic database through which we direct the periodicity of maintenance. Each technical project acquires an identity, and we can monitor its maintenance separately. In this way, we prevent a lot of damage and act more on prevention than on repair as has been done so far.

In the present paper, the development of the decision-making web-tool is described, and a real case example is presented in detail to demonstrate effectively the tool's application and resulting advantages.

\section{Materials and Methods}

\subsection{The Rainfall-Runoff Simulation Model \\ 2.1.1. HEC-GeoHMS Modelling}

In this research, the preparation of the hydrologic model was performed via HECGeoHMS version 10.6. The model preparation was comprised of four main steps: terrain preprocessing, project setup, stream and watershed characteristics, and parameterization. Data acquisition, such as digital elevation model (DEM), soil data map, and land use map is considered as the starting point of the terrain preprocessing phase. The DEM was acquired from the Hellenic Military Geographical Service (HMGS) and was used to extract the stream network of the study area (DEM resolution is $5 \mathrm{~m}$ ). Terrain preprocessing requires the DEM and the steam network as input data and consists of ten main steps that enable the watershed and stream delineation. The main steps are as follows: DEM reconditioning, fill sinks, flow direction, flow accumulation, stream definition, stream segmentation, catchment grid delineation, catchment polygon processing, drainage line processing, and adjoint catchment processing. Terrain preprocessing can also be performed by employing arc-hydro tools [21].

The terrain preprocessing data determine the input data for the project setup. The project setup menu enables the stakeholders to define an outlet point for the basin under study. As a result, ten outlet points, one for each sub-basin, representing the location 
of the corresponding technical works (culverts), were generated in this research. When watershed and stream have been delineated, the stream and watershed characteristics menu facilitates the extraction of physical characteristics such as river length, river slope, basin slope, longest flow path, basin centroid, centroid elevation, and centroidal longest flow path of the study area [23]. These physical characteristics were used to calculate the hydrologic parameters of the basin [21].

The next step includes the parameterization tools such as the river auto name and the basin auto name that assign a name to sub-basins and sub-streams of the study area. The final step of the rainfall-runoff model preparation consists of the following: modification of the map to HMS units, final data check, HMS schematic generation, adding of coordinates, and the data preparation for the HEC-HMS. The final outputs of HEC-GeoHMS are the following: background shape file, basin model file, gage model file, and met model file. Then, the hydrologic model is ready to be exported to HEC-HMS software.

\subsubsection{HEC-HMS Modelling}

The hydrological model enables the stakeholders to perform the precipitation-runoff simulation in a wide range of geographical areas [24,28]. In this study, hydrological modeling was conducted by employing HEC-HMS 3.5. The model requires the hydrologic parameters derived from HEC-GeoHMS as input data. The simulation model comprised three main components: basin model, meteorological model, and control specification.

The basin model represents the study area and involves the transformation of atmospheric precipitation into runoff. SCS curve number and SCS unit hydrograph were selected as loss and transform methods, respectively. The SCS CN loss method estimates the direct runoff utilizing the curve number as input parameter [27]. The $\mathrm{CN}$ estimates the amount of total runoff as a function of soil cover and land use. In this research, the soil map USDA texture, acquired from the European Soil Data Centre, was used to define the soil cover (ESDAC) $[29,30]$. There are four hydrologic soil groups based on soil texture and infiltration (A, B, C, and D). Group A represents high infiltration capacity, while group D represents low infiltration capacity [31]. Land use was obtained from the Corine 2000 Land Cover database. Therefore, the SCS CN method was estimated by using the following equations:

$$
\begin{gathered}
\text { Weighted } \mathrm{CN}=\frac{\sum_{i=1}^{n} E_{i} \times C N_{i}}{\sum_{i=1}^{n} E_{i}} \\
S=\frac{25400}{C N}-254 \\
P_{e}=\frac{\left(P-I_{a}\right)^{2}}{\left(P-I_{a}\right)+S} \\
P_{e}=0 \text { for } P \leq 0.2 \times S \text { and } I^{a}=0.2 \times \mathrm{S}
\end{gathered}
$$

where: $P_{e}$ effective precipitation $(\mathrm{mm}) ; P=$ precipitation depth $(\mathrm{mm}) ; I^{a}=$ the initial abstraction $(\mathrm{mm})$ or the amount of water before runoff; $S=$ the potential maximum retention $(\mathrm{mm})$ after runoff begins; $\mathrm{CN}=$ curve number; and $E_{i}=$ area.

The SCS unit hydrograph transform method was used to estimate the direct runoff. Meteorological data were obtained from the meteorological station of Kastaneri (Figure 1). The lag time $\left(T_{l a g}\right)$ is the only required input data. The lag time was calculated for each sub-basin using the following equations:

$$
\begin{gathered}
T_{t}=\frac{L}{60 \times V} \\
U=\frac{1}{n} \times R^{\frac{2}{3}} \times J^{\frac{1}{2}}
\end{gathered}
$$


where: $T_{t}=$ time lag $(\mathrm{min}), L=$ length of flow $(\mathrm{m}), V=$ velocity $(\mathrm{m} / \mathrm{s}), R=$ hydraulic radius $(\mathrm{m}), J=$ slope of the hydraulic grade line or the linear hydraulic head loss, and $\mathrm{n}=$ Manning coefficient.

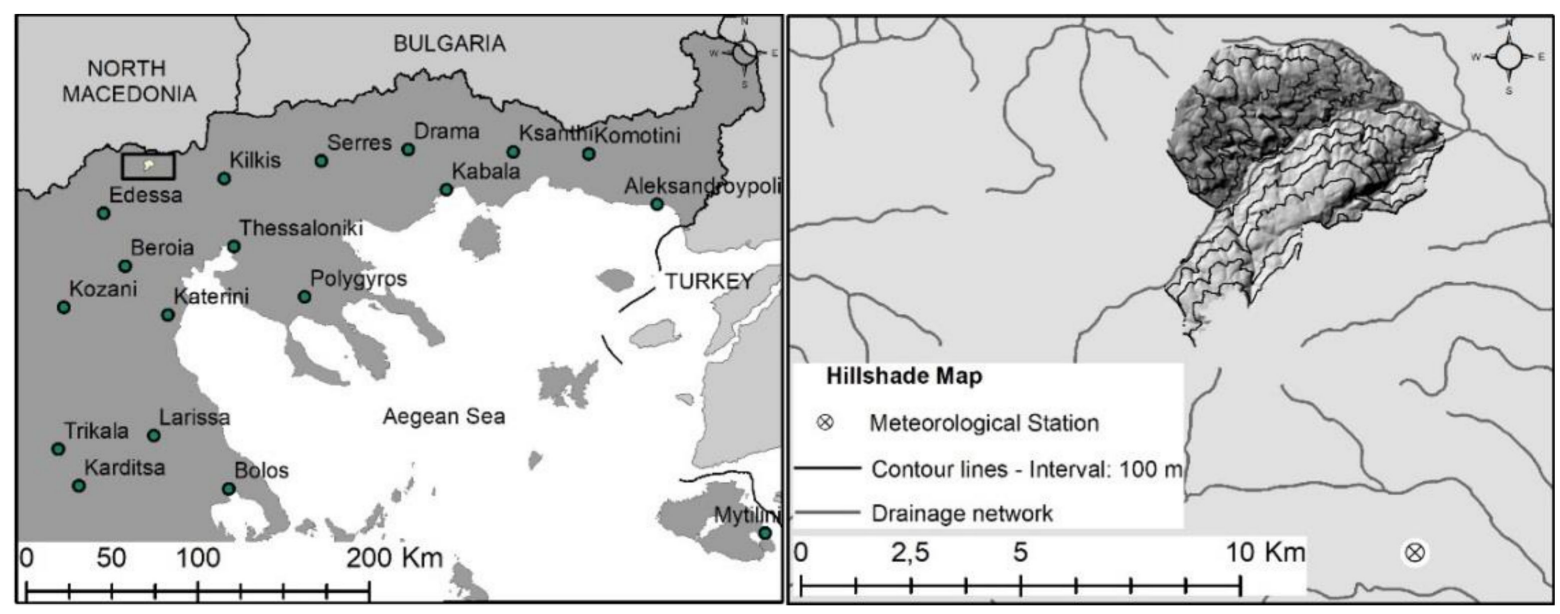

Figure 1. Location map of the case study area.

The time-series data function was used to assign the precipitation data to the meteorological model. Six-minute time interval was used for the simulation model. Due to the scarcity of reliable rainfall recorded data, the Gumbel distribution type II was applied to the time-series of precipitation data with a 25-year return period. According to [32], the Gumbel distribution is based on the following equations:

$$
\begin{gathered}
F(x)=e^{-e^{-y}} \\
\frac{1}{T}=1-e^{-e^{-y}} \\
y=-\ln \ln \frac{T}{T-1}
\end{gathered}
$$

where: $F(x)=$ the probability of non-exceedance, $T=$ return period.

The specified hyetograph method was applied to the meteorological model. The timeseries data were assigned to all sub-basins of the Koupa watershed. Control specification enables the stakeholders to define the time interval parameter and the starting and ending points of the simulation.

\subsection{Calculation of Drainage Capacity of Technical Projects in the Koupa Area}

In a watershed where no instruments are installed, the estimation of the maximum water-carrying capacity of the torrent can be calculated indirectly if the cross-sectional area of the channel and the average flow velocity of the effluent water are known, based on the following equation $[33,34]$ :

$$
Q=V \times A
$$

where $Q$ denotes the flow rate in $\mathrm{m}^{3} / \mathrm{s}, A$ is the cross-sectional area of the stream in $\mathrm{m}^{2}$, and $V$ is average flow rate $(\mathrm{m} / \mathrm{s})$. Next, the flow rate can be determined based on the Manning equation:

$$
V=\frac{1}{n} \times R^{\frac{2}{3}} \times J^{\frac{1}{2}}
$$

In the above equation, the Manning coefficient $(V)$ is an indicator of the resistance that the material of the riverbed displays to the flow of the watercourse. The hydraulic radius $R$ is the quotient of the cross-sectional area through the wetted perimeter of the cross-section, 
while $J$ denotes the slope of the riverbed. Combining Equations (10) and (11), the average flow velocity of the effluent water can be expressed as:

$$
Q=A \times \frac{1}{V} \times R^{\frac{2}{3}} \times J^{\frac{1}{2}}
$$

Utilizing the real values of parameters in equation (12), corresponding to the forest operations in the area of interest (Koupa basin), i.e., $A=0.502655 \mathrm{~m}^{2}, R=0.4 \mathrm{~m}, V=0.015$, and $J=4 \%$, provides an estimate of $Q=2.29 \mathrm{~m}^{3} / \mathrm{s}$. We should note that for the 10 culverts in our illustration example, the same parameters previously described were utilized since all examined culverts had the same characteristics (cross-section, bottom type-material, and slope).

\subsection{The Online Platform for the Management of Forest Operations}

This study contributes to the development of a decision-making platform for the management of forest engineering projects. The platform provides visualization of forest operations and uses appropriate algorithms to identify potentially dangerous technical projects. In summary, this web application uses a SQL Server database, a Map Server to present the results, and a Web Application.

\section{Results}

\subsection{Study Area}

The developed platform may prove a useful tool in the hands of various organizations and actors involved in the management of forest operations and in their efforts to prevent potential disasters in an effective way. For a demonstration of its potential applications and the resulting advantages from its use, a real case example of a mountainous area in Northern Greece is selected (i.e., Koupa watershed).

Specifically, the research area, namely, the Koupa forest, is located in the Kilkis prefecture, Region of Central Macedonia, Northern Greece (Figure 1).

The forest occupies the northeastern slopes of Mount Paiko. The selected area was found to cover $24.7 \mathrm{Km}^{2}$ using GIS map information. The main forest species are oaks, i.e., species that can produce technical wood. The forest of Koupa presents a varied geomorphological relief. Its altitude varies between 380 and $1.252 \mathrm{~m}$. The study area consists of the following altitude zones: hilly areas (11.2\%), semi-mountainous areas $(60.3 \%)$, and mountainous areas $(28.5 \%)$. There are many ridges across the forest in any direction, creating a variety of environments and orientations. Additionally, corresponding streams and tremors are often encountered in this forest area (Source: Local Forestry Service management plan 2018-2028).

The Northern exposure of most of the forest can lead to significant forest road problems. Taking into account the climate conditions of the area, in conjunction with the horticultural formation and the fact that most of the forest road network is a C-class forest road (there are four main road categories in Greece, namely, A, B, C, and tractor roads. According to 92833/4679/1-12-97 Decision of the Greek Ministry of Agriculture, the features of a C class road are road width: 4-5 m; minimum radius of curvature: $20 \mathrm{~m}$; and grade slope up to $12 \%$ (for the construction of a C class road, engineering structure, side ditch, and slope formation is required)), it is understood that after each winter period most of the forest road network needs important repair, rendering this forest area most suitable for the present application.

\subsection{An Application Example of WEB Platform in a Greek Forest}

Among the most common problems in forest operations engineering is insufficient maintenance, blocked tubes, and the poor state of repair of all infrastructures. This paper describes the development and application of a web-based decision-making tool and outlines an example to prove its application and the resulting benefits. The proposed application can be used in a series of forestry projects, such as drainage systems, side 
ditches, and retaining and supporting walls. Figure 2 provides an analytical description of potential technical projects that can be effectively managed through the proposed web-tool.

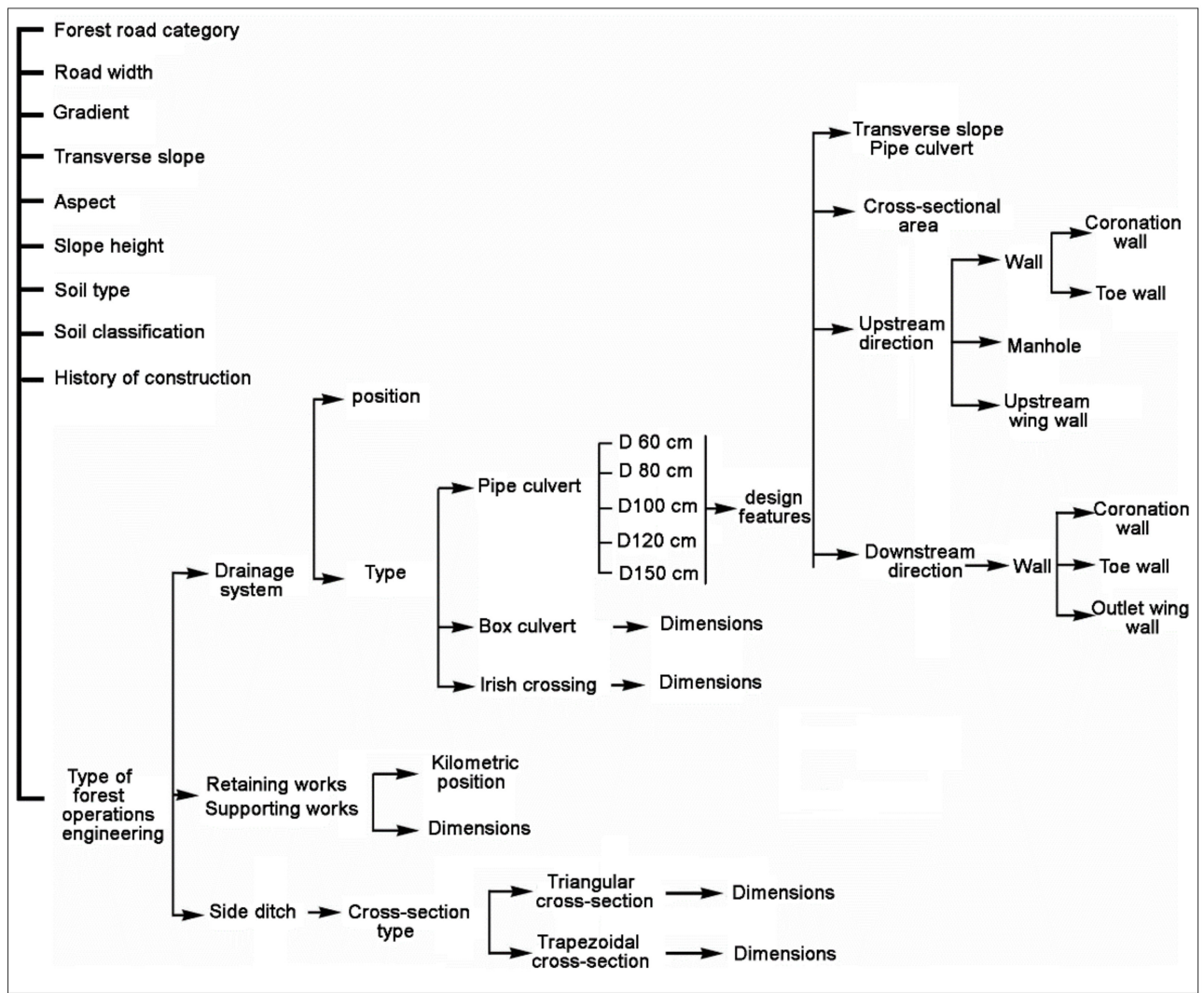

Figure 2. Categories of forest operations.

By using the platform, any forest service officer or visitor, while browsing and utilizing the proposed web platform, can report any problem (in a list of 6 possible options, namely, small surface damage, circumferential crack, longitudinal or multiple cracking, loss of level, multiple fractures and deformation, and collapsed-blocked) in a technical project, thus creating a real-time database (see Figure 3).

\section{Forest Map - Forest Operations Engineering Home}

\section{Details}

Maintenance History

$$
\begin{array}{rl|}
\text { Destruction Type } & \text { destruction of coronation wall downstream } \\
\text { Date } & 03 / 04 / 2019 \text { 12:00:00 AM } \\
\text { Is Completed } & \text { True } \\
\text { Is Scheduled } & \text { Not Set } \boldsymbol{} \\
&
\end{array}
$$

Figure 3. The "Maintenance History" display screen of the web application tool.

In order to demonstrate the utilization of the web platform in performing forest operations, an illustration example associated with problems related to the drainage system of the case study region is described. 
Specifically, the demonstration includes the checking of the status of 10 culverts located in corresponding sub-basins of the region, identifies the problematic culverts, and updates the status of the drainage system of the specific technical works and culverts after repairs. This procedure can be also adopted for the other forest works, as described in Figure 2.

The following figures describe the main tasks concerning the drainage systems that can be accomplished through the implementation of the web-platform. In particular, the "Details" display screen of Figure 3 of the web-tool shows "Maintenance History", which presents to the user useful information, such as the last time a maintenance project was carried out, which problems have occurred in the past, when the next maintenance is planned, and which tasks it may contain.

The display screen named "Edit" can be used by the user of the application in order to edit the current information and insert updated information related to forest operations (Figure 4). By recording minimal data, users can acquire a more thorough picture of the state all technical works are in.

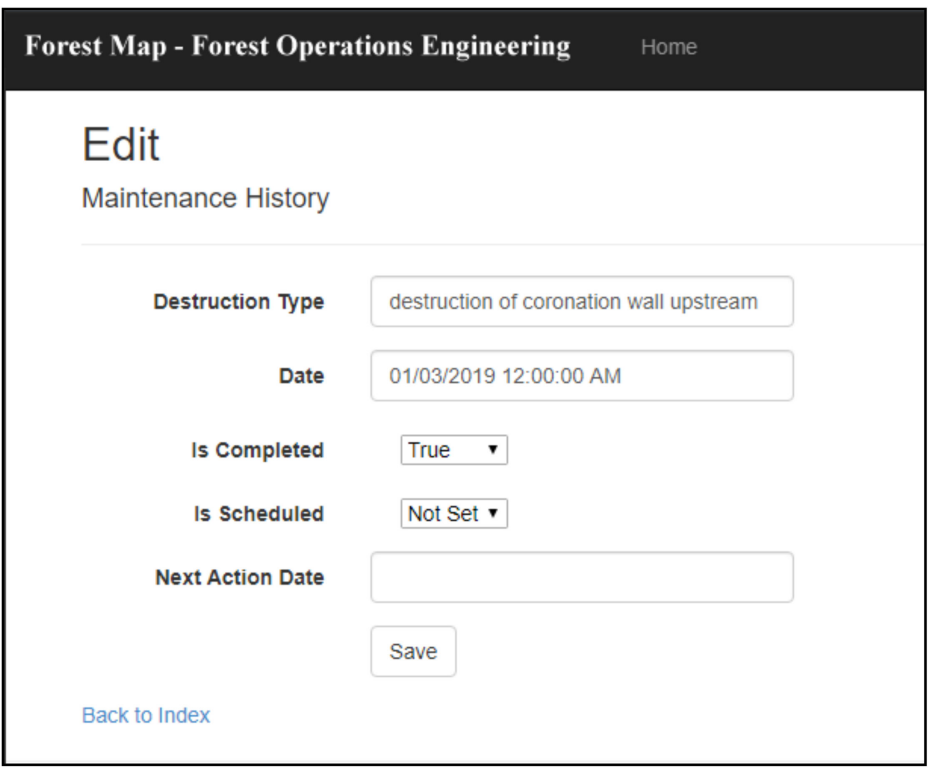

Figure 4. The "Edit" display screen of the web application tool.

\subsubsection{Precipitation-Runoff Simulation via the HEC-GeoHMS}

Basin delineation was performed using the HEC-GeoHMS 10.6. The main output data of this pre-processing step are the following: agree DEM, fill sinks, flow direction, flow accumulation, stream definition, stream segmentation, catchment grid delineation, catchment polygon processing, drainage line processing, and watershed aggregation. The land use classes and the hydrologic soil groups are derived from Corine 2000 Land Cover database and the soil map USDA texture, respectively. Table 1 illustrates the land classes of the study area. The study area consists of forests $\left(21.9 \mathrm{~km}^{2}\right)$, agricultural lands $\left(2.2 \mathrm{~km}^{2}\right)$ and meadows $\left(0.6 \mathrm{~km}^{2}\right)$.

Table 1. CN look-up table.

\begin{tabular}{ccc}
\hline \multirow{2}{*}{ Land-Use Types } & \multicolumn{3}{c}{ Hydrologic Soil Groups } \\
\cline { 2 - 3 } & B & D \\
\hline Agricultural field & 78 & 89 \\
Forest/forest areas & 60 & 79 \\
Meadows & 58 & 78 \\
\hline
\end{tabular}


Soil classification has been based on texture and infiltration. According to Al Marsumi (2017), there are four hydrologic soil groups: A, B, C, and D. Soil group A represents high infiltration, while soil group $D$ represents low infiltration. The soil in the study area was classified, according to the aforementioned classification, mainly as types B $\left(24.5 \mathrm{~km}^{2}\right)$ and $\mathrm{D}\left(0.2 \mathrm{~km}^{2}\right)$.

The curve number for the Koupa watershed was estimated by employing ArcGIS 10.6 software [35] to combine the land uses with the hydrologic soil groups, in order to calculate the runoff $\mathrm{CN}$ per land-use type (Table 1). Therefore, the $\mathrm{CN}$ was estimated for each sub-basin and then by using equations (1) to (4), and the areal-weighted $\mathrm{CN}$ was found to be equal to 61.71 .

\subsubsection{HEC-HMS Results}

The rainfall-runoff simulation model was applied by using SCS-CN and SCS unit hydrograph as loss and transform method, respectively. Precipitation analysis was conducted applying the specified hyetograph method. The study area was divided into 10 sub-basins. The outlet point of each sub-basin represents the exact location of the corresponding culvert.

W8 sub-basin (Figure 5) shows the highest total loss compared to other sub-basins (Table 2). The six-minute time interval was defined as input parameter in the meteorological model. The simulation model generates similar hydrographs for all the sub-basins, due to their small size. Figure 6 illustrates a representative runoff hydrograph, which constitutes a graphical representation of runoff rate against time.

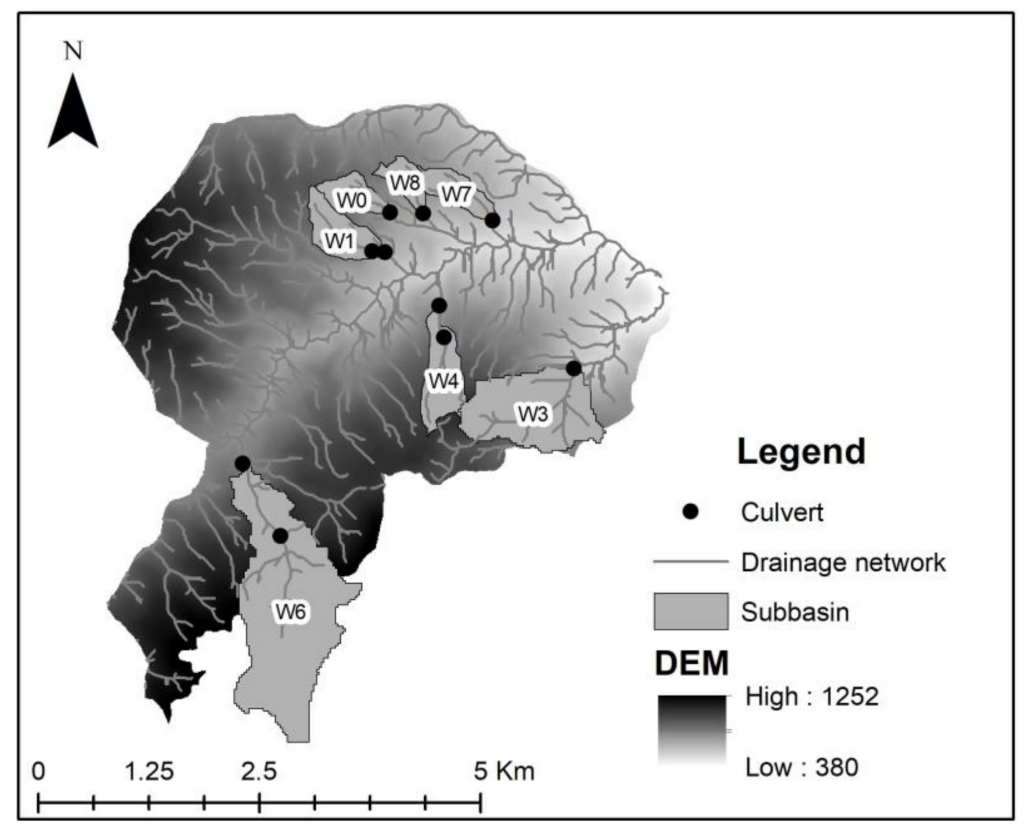

Figure 5. The sub-basins of the Koupa basin.

Table 2. Peak and total loss per sub-basin in $\mathrm{m}^{3} / \mathrm{s}$.

\begin{tabular}{cccccc}
\hline Sub-Basin & Peak Discharge & Total Loss & Sub-Basin & Peak Discharge & Total Loss \\
\hline W0 & 1.6 & 4.6 & W5 & 8.3 & 38.9 \\
W1 & 2.6 & 7.3 & W6 & 5.1 & 47.7 \\
W2 & 2.5 & 7.2 & W7 & 1.7 & 5.1 \\
W3 & 6.7 & 22.3 & W8 & 1.3 & 3.5 \\
W4 & 2.0 & 8.8 & W9 & 1.7 & 6.2 \\
\hline
\end{tabular}




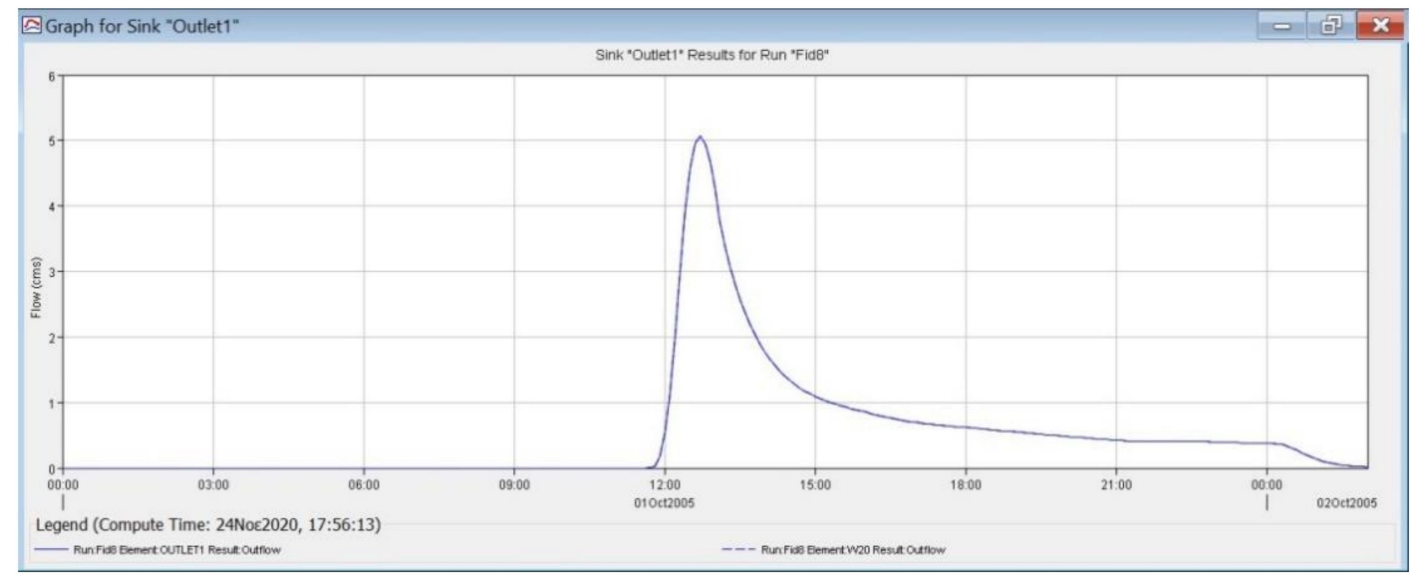

Figure 6. Simulation result for $24 \mathrm{~h}$ extreme storm event.

3.2.3. Results of the Web-Based Application in Koupa Watershed, Northern Greece

The web-tool, using real meteorological data, combined with the rainfall-runoff simulation model for water supply calculations, along with the estimation of the average flow velocity of the effluent water in the specific region of Koupa, can be subsequently used for the identification of the high-risk related areas within the study region.

Specifically, the decision-making web-tool system checks the status of the "Forest operations" that we have stored and accordingly colors the points on the map to define maintenance issues (red and blue colored indicators in the display map of Figure 7 below).

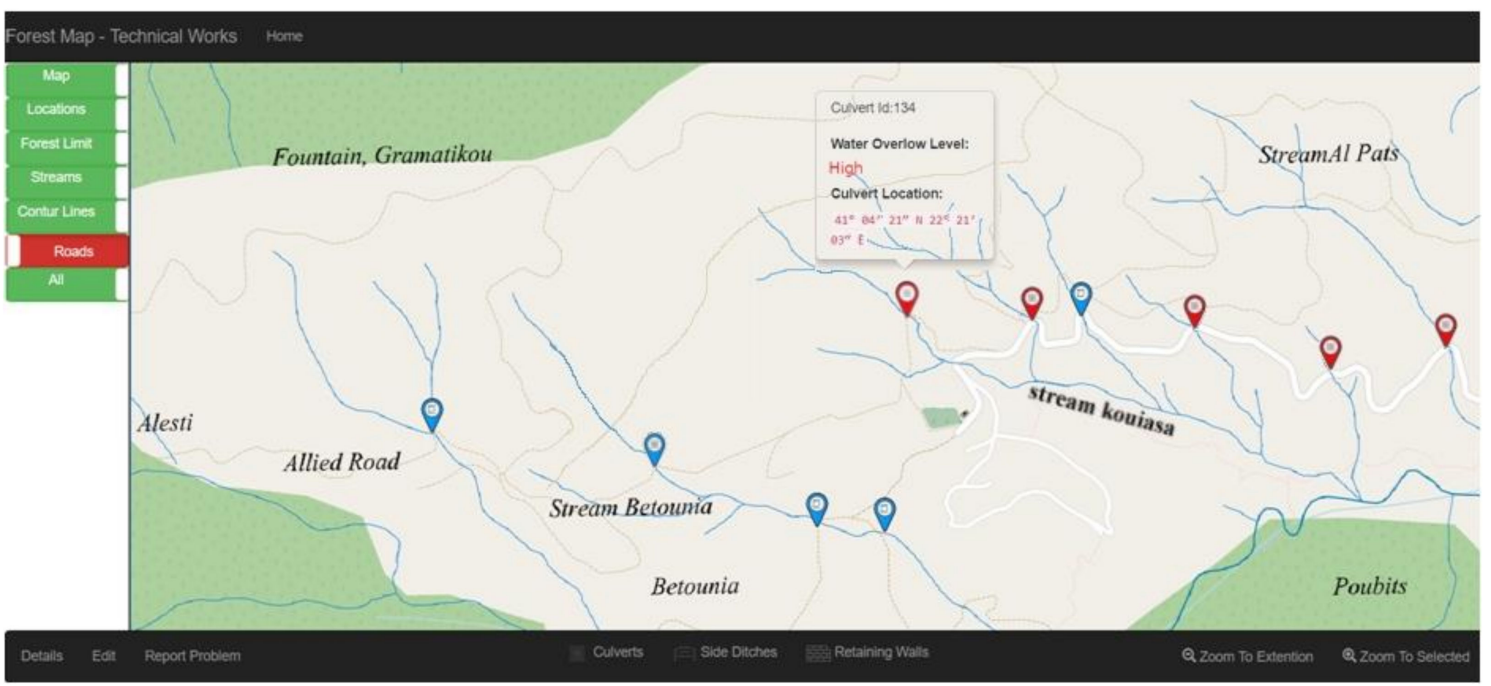

Figure 7. Display map of forest technical works at risk (indicated with red color).

For our illustrative example, we have selected a total of 10 forest operations within the ten sub-basins that have been utilized for rainfall-runoff simulations via the HEC-HMS. The web-tool, combining the information embedded regarding the peak discharge per sub-basin (see Table 2) with the average flow velocity of the effluent water running through the drainage infrastructure and culverts in the ten sub-basins (i.e., $Q=2.29 \mathrm{~m}^{3} / \mathrm{s}$ ), results in the following risk map (Figure 7). Hence, Figure 7 shows the resulting map of the area with indicated forest operations that need to be addressed.

As one observes, we have indications that among the ten forest operations in the Koupa region, and half of them will be confronted with a water drainage problem within the next 25 years. 
It should be mentioned that all forest operations in the research area that we refer to concern tubular $80 \mathrm{~cm}$ diameter culverts with shafts upstream and without exit works from the culvert. Hence, from our analysis and utilization of the web-based tool for identifying risks in technical works in the Koupa region, among the 10 technical works examined, we can deduce that half of them meet the specifications required for the specific characteristics of the region, whereas the rest fail to do so.

As a next step in our illustrative application of the decision making tool, after the identification of problematic forest operations in the specific region of interest, the user can update the status of the specific technical work to "completed" so that the system can re-mark the technical work as a low-risk project.

\section{Discussion}

Forest maintenance operations such as drainage infrastructure systems and culverts, retaining/supporting walls, and side ditches constitute an important portion of highway assets that requires routine inspections, maintenance, and timely repair and renewal [36]. Especially, drainage infrastructure systems need special attention in terms of development and application of proactive and preventive asset management strategies. Recent surveys demonstrate that there is a lack of nationwide recognition regarding the importance of culvert management procedures [36].

Especially, the loss of culvert integrity in drainage systems could result in temporary roadway closure and considerable rehabilitation/replacement costs or worse. In addition, the total collapse of a culvert could pose a major safety risk to motorists. Hence, culverts should be routinely inspected and condition state determined to estimate the remaining service life with a view to proposing corrective actions so as to prevent costly culvert failures [37]. Furthermore, lack of maintenance can result in detention or retention basins being filled with sediment or debris. If these basins are already full of sediment or debris, they cannot store water and flooding can result because the drainage system cannot do its job [38].

GISs can provide an understanding of landscapes and features to support decisionmaking processes in many fields of research and corresponding applications [39]. There are many potential forest operations for which a decision-making tool based on geographical information can be utilized.

In the current study, we develop a decision-making platform for forest operations management, by combining information derived from rainfall-runoff simulation with GIS software. The developed platform can provide information related to operations planning and management (e.g., reducing vulnerability of roads to environmental damage) in a typical forest environment.

More specifically, first we utilized the Hydrologic Engineering Center-Geospatial Hydrologic Modeling System (HEC-GeoHMS) for the geospatial analysis of forest watersheds, and the hydrologic engineering center-hydrologic modeling system (HEC-HMS) to properly quantify the runoff generated in the watershed under study. At a second stage, to delineate the physical characteristics of the watershed, soil data and land use maps were incorporated in the model, embedded within the developed web-tool. The Gumbel distribution type II was used to obtain the maximum flood discharge in 25 years flood. This model incorporates the soil conservation service (SCS) curve number $(\mathrm{CN})$ approach as a loss method and the SCS unit hydrograph method for the outflow estimation. Then, the developed decision-making platform uses the information derived from the rainfall-runoff simulations to provide information related to forest operations planning and management, especially associated with the potentially dangerous technical projects such as problematic drainage infrastructures and culverts.

An additional important feature of the created platform is that it can serve as a comprehensive database of technical projects that have been performed in an area. After the recording of the positions as well as the characteristics of the projects and repairs that have been performed, the user of the platform has the opportunity to keep track of this information in selected periods of time. Culvert maintenance is one of the key elements 
of a working highway drainage system. Timely maintenance activities reduce the risk of future problems related to the structural, hydraulic, and durability aspects. Culvert maintenance activities include inspecting the culverts for current performance; removing debris, sedimentation, and dirt from the culverts; and identifying the probable problems that may occur in the future.

More specifically, this platform attempts a thorough management of the problems of forest operations engineering, with emphasis on transportation systems planning and management (i.e., forest roads and culverts) through a unified approach. In particular, the application proposes a systematic information decision tool that is structured around three main axes: a) diagnosis, b) prediction, and c) planning. It provides a handy and useful solution that combines geo-environmental and geospatial technologies to effectively facilitate the management of forest operations engineering. The application of the proposed tool was demonstrated based on an example of an existing forest area in Greece. Based on the above example, we managed to offer the following benefits to the forest service that is already using the application:

- $\quad$ Reduction of maintenance costs due to systematic programming.

- Reduction of the likelihood of accidents due to poorly maintained or unsupervised forest operations.

- Modernization and organization of the technical department.

We have to note at this point that, although in our specific example of utilization of the online platform we refer to culvert maintenance and inspection, we could easily extend the application to other projects such as drainage systems or side ditches.

As regards the selected case study area for the demonstration of the proposed platform (a forest located in the region of Central Macedonia, Northern Greece), this choice was deemed as most suitable since its location and exposure to diverse and extreme environmental conditions typically lead to significant problems in forest infrastructures.

As a result of these conditions, both in the past and today, the local forest service, according to their reports, were lagging behind in the organization and maintenance of forestry projects. A fundamental and timeless problem is the lack of an organized database for such projects. The difficulty they are faced with in performing timely maintenance is due to the fact that forest authorities do not know when the technical works of their territory were constructed, with what specifications, and in which locations. Additionally, the constructions and repairs were performed without any formal studies on the landscape characteristics or culvert drainage features, such as water supply and/or sediment transportation.

In addition, specifications are considerably outdated since the specifications for the current works date back to the 1980s. In the same vein, in many instances, specifications and standards designed for the national highway (i.e., Egnatia Road) are frequently utilized due to lack of more specialized specifications that are suitable for forest areas, something that is not completely acceptable for the conditions that exist in an inland environment, such as the one of the case study. An equally important problem is the choice of dimensions for the forest operations and specifically for the tubular culverts, since up to now the choice of the right dimensions is done empirically. One may add to the above problems and issues the fact that especially in the 70s and 80s when most road network openings took place, in many instances the lack of official and effective designing of opening a road resulted in a wide road network lacking support in terms of technical works. As a consequence of improper construction of culverts in forest roads and their poor maintenance, there are major issues both in their solid supply as well in their water supply, the former being the more serious problem in tubular culverts in Greece, since when the technical pipeline does not have the proper inclination then the possibility to fail and crumble is higher.

As a direct result of these actions, the current constructions and maintenance practices do not completely cover the local needs of the area and more money is spent for the construction of a technical project. In [40], it has been shown that for the Greek regions there is a direct correlation of public expenditure with the length of the road network improved, hence our approach can be seen as a tool for improvements in management and reduced 
expenditures in technical projects. This derives from the fact that the maintenance cost analysis for road drainage ditches is achieved by knowing the extent and size of the damage. With the utilization of the proposed platform, we know from the beginning how much each maintenance operation costs, so we can monitor and record the costs of each maintenance in a suitable way. Costs are also significantly reduced by the appropriate setting of the maintenance frequency through the platform, which depends on the information we have regarding each project, i.e., how often damage occurs; meteorological data, etc.; and the records we have in the platform's database (maintenance history). For example, areas with north slopes need more frequent maintenance. Finally, given the way the application works, the data collected and powered by the database come from different sources such as the forest officials, drivers, security guards, and scientific and labor personnel, according to their movements in the wider area of the forest region. In this way, inspections by the forest service are done purposefully, thus resulting in cost reductions.

\section{Conclusions}

The proposed decision-making tool can significantly assist the local forest services in the specific region as well as in other forestry regions towards a unified and effective management of forest operations by both updating the database of conducted forest operations in a spatial manner, and by providing information on forest operations most likely to be at risk via a real-time application.

Finally, as a venue for further research, we must note that future applications of the proposed web tool may be extended via the further development of the current platform to a fully automated web application that can provide assistance to various forest authorities for the management of forest operations engineering and related issues in an efficient and sustainable way. Additionally, introducing the option of choosing alternative mathematical formulas for the calculation of water supply may enhance the effectiveness of the application.

Author Contributions: Conceptualization, A.K., C.M., and G.A.; Methodology, A.K., C.M., A.S., N.T., S.T., and G.A.; Software, A.K., C.M., A.S., N.T., and S.T.; Writing—original draft preparation, A.K., C.M., A.S., N.T., S.T., and G.A.; Writing—review and editing, A.K., C.M.; Data, A.K., C.M., N.T., and G.A. All authors have read and agreed to the published version of the manuscript.

Funding: This research received no external funding.

Institutional Review Board Statement: Not applicable.

Informed Consent Statement: Not applicable.

Data Availability Statement: The data are not publicly available due to institutional property rights.

Acknowledgments: The authors wish to thank Zoe Malivitsi for editing the paper.

Conflicts of Interest: The authors declare no conflict of interest.

\section{References}

1. Lugo, A.E.; Gucinski, H. Function, effects, and management of forest roads. For. Ecol. Manag. 2000, 133, 249-262. [CrossRef]

2. Majnounian, B.; Nikooy, M.; Mahdavi, M. Cross drainages design of forest road in shafarood basin, guilan province Iran. J. Nat. Res. 2005, 58, 339-350.

3. Stergiadou, A.; Valese, E.; Lubello, D. Detailed cartography system of fuel types for preventing forest fires. In Proceedings of the 6th International Workshop of EARSEL, Thessaloniki, Greece, 27-29 September 2007; pp. 120-124.

4. Demir, M. Impacts, Management and Functional Planning Criterion of Forest Road Network System in Turkey. Transp. Res. Part A Policy Pract. 2007, 41, 56-68. [CrossRef]

5. Hayati, E.; Majnounian, B.; Abdi, E.; Sessions, J.; Makhdoum, M. An Expert-based Approach to Forest Road Network Planning by Combining Delphi and Spatial Multi-criteria Evaluation. Env. Monit. Assess. 2013, 185, 1767-1776. [CrossRef]

6. Alizadeh, S.M.; Majnounian, B.; Darvishsefat, A.A. Possibility of designing and evaluation of forest road network variants using GIS and field investigation (case study: Kheiroud forest Chelir district). J. For. Wood Pro. 2011, 63, 399-408.

7. Kantartzis, A.; Malesios, C. A Decision Support System Web-Application for the Management of Forest Road Network. J. Environ. Sci. Eng. A 2018. [CrossRef] 
8. Talebi, M.; Majnounian, B.; Abdi, E.; Tehrani, F.B. Developing a GIS Database for Forest Road Management in Arasbaran Forest, Iran. For. Sci. Technol. 2015, 11, 27-35. [CrossRef]

9. Cafferata, P.H. Designing Watercourse Crossings for Passage of 100-Year Flood Flows, Wood, and Sediment; California Department of Forestry and Fire Protection: Sacramento, CA, USA, 2004; Updated 2017.

10. Furniss, M.J.; Ledwith, T.S.; Love, M.A.; McFadin, B.C.; Flanagan, S.A. Response of Road-Stream Crossings to Large Flood Events in Washington, Oregon, and Northern California. Available online: https://www.fs.fed.us/t-d/pubs/html/wr_p/98771807/98771807. htm (accessed on 1 November 2020).

11. Myronidis, D.; Stathis, D.; Sapountzis, M. Post-Evaluation of Flood Hazards Induced by Former Artificial Interventions along a Coastal Mediterranean Settlement. J. Hydrol. Eng. 2016, 21, 05016022. [CrossRef]

12. Solomon, S.; Qin, D.; Manning, M.; Chen, Z.; Marquis, M.; Averyt, K.B.; Tignor, M.; Miller, H.L. Contribution of Working Group I to the Fourth Assessment Report of the Intergovernmental Panel on Climate Change; IPCC: Cambridge, UK; New York, NY, USA, 2007.

13. Villarini, G.; Scoccimarro, E.; Gualdi, S. Projections of heavy rainfall over the Central United States based on CMIP5 models. Atmos. Sci. Lett. 2013, 14, 200-205. [CrossRef]

14. Xu, H.; Muste, M.; Demir, I. Web-based geospatial platform for the analysis and forecasting of sedimentation at culverts. J. Hydroinform. 2019, 21, 1064-1081. [CrossRef]

15. Eskioglou, P.; Stergiadou, A. Low—value forest road-pavement thickness computation for environmental protection. In Proceedings of the Protection and Restoration of the Environment VIII, Chania, Greece, 3-7 July 2006; pp. 507-508.

16. Kantartzis, A. Databases of Forest Road Construction in the Context of Forest Cadastral. Ph.D. Thesis, Department of Forestry and Management of the Environment and Natural Resources, Democritus University of Thrace, Xanthi, Greece, 2015. Available online: https:/ / thesis.ekt.gr/thesisBookReader/id/36578\#page/1/mode/2up (accessed on 25 January 2021).

17. Najafi, A.; Richards, E.W. Designing a Forest Road Network Using Mixed Integer Programming. Croat. J. For. Eng. 2013, 34, 17-30.

18. Xu, H.; Demir, I.; Koylu, C.; Muste, M. A web-based geovisual analytics platform for identifying potential contributors to culvert sedimentation. Sci. Total Environ. 2019. [CrossRef] [PubMed]

19. Joshi, N.; Bista, A.; Pokhrel, I.; Kalra, A.; Ahmad, S. Rainfall-Runoff Simulation in Cache River Basin, Illinois, Using HECHMS. In World Environmental and Water Resources Congress, 2019: Watershed Management, Irrigation and Drainage, and Water Resources Planning and Management; American Society of Civil Engineers: Pittsburgh, PA, USA, 2019; Available online: https: / / digitalscholarship.unlv.edu/fac_articles/663/ (accessed on 25 January 2021).

20. Moraes, T.C.; Santos, V.J.; Calijuri, M.L.; Torres, F.T.P. Effects on runoff caused by changes in land cover in a Brazilian southeast basin: Evaluation by HEC-HMS and HEC-GEOHMS. Environ. Earth Sci. 2018, 77, 250. [CrossRef]

21. Ramly, S.; Tahir, W. Application of HEC-GeoHMS and HEC-HMS as Rainfall-Runoff Model for Flood Simulation. In Proceedings of the International Symposium on Flood Research and Management; Springer: Singapore, 2015; pp. 181-192.

22. Strapazan, C.; Petrut, M. Application of Arc Hydro and HEC-HMS Model. Techniques for Runoff Simulation in the Headwater Areas of Covasna Watershed (Romania). Geogr. Tech. 2017, 12, 95-107. [CrossRef]

23. USACE. User's Manual HEC-GeoHMS 10.1; Hydrologic Engineering Center-Geospatial Hydrologic Modelling System; US Army Corps of Engineers: Washington, DC, USA, 2013.

24. USACE. User's Manual HEC-HMS 3.5; Hydrologic Engineering Center-Geospatial Hydrologic Modelling System; US Army Corps of Engineers: Washington, DC, USA, 2010.

25. Gumindoga, W.; Rwasoka, D.T.; Nhapi, I.; Dube, T. Ungauged runoff simulation in Upper Manyame Catchment, Zimbabwe: Application of the HEC-HMS model. Phys. Chem. Earth Parts A/B/C 2017, 100, 371-382. [CrossRef]

26. Halwatura, D.; Najim, M.M.M. Application of the HEC-HMS model for runoff simulation in a tropical catchment. Environ. Model. Softw. 2013, 46, 155-162. [CrossRef]

27. Tassew, B.G.; Belete, M.A.; Miegel, K. Application of HEC-HMS Model for Flow Simulation in the Lake Tana Basin: The Case of Gilgel Abay Catchment, Upper Blue Nile Basin, Ethiopia. Hydrology 2019, 6, 21. [CrossRef]

28. Theofanous, N.; Myronidis, D. A streamflow hydrograph analysis and simulation for a study case watershed. Int. J. Sustain. Agric. Manag. Inform. 2020, 6, 94-105.

29. Ballabio, C.; Panagos, P.; Montanarella, L. Mapping topsoil physical properties at European scale using the LUCAS database. Geoderma 2016, 261, 110-123. [CrossRef]

30. Topsoil Physical Properties for Europe (Based on LUCAS Topsoil Data). Available online: https:/ / esdac.jrc.ec.europa.eu/content/ topsoil-physical-properties-europe-based-lucas-topsoil-data (accessed on 26 April 2021).

31. Al Marsumi, J.K.; Al Shamma, M. Classification of soil infiltration rate depending on the hydrological soil group map South East Iraq. J. Sci. 2017, 58, 2165-2171.

32. Ponce, V.M. Engineering Hydrology, Principles and Practices; Prentice Hall: Hoboken, NJ, USA, 1989; pp. $223-226$.

33. Sgouropoulou, K.; Myronidis, D. Stream Peak discharge computations regarding the assessment and management of floods within the framework of the EU directive. In Proceedings of the 10th International Hydrogeological Congress, Thessaloniki, Greece, 8-10 October 2014.

34. Myronidis, D.; Ivanova, E. Generating regional models for estimating the peak flows and environmental flows magnitude for the Bulgarian-Greek Rhodope mountain range torrential watersheds. Water 2020, 12, 784. [CrossRef]

35. Zhan, X.; Huang, M.-L. ArcCN-Runoff: An ArcGIS tool for generating curve number and runoff maps. Environ. Model. Softw. 2004, 19, 875-879. [CrossRef] 
36. Salem, O.; Salman, B.; Najafi, M. Culvert Asset Management Practices and Deterioration Modeling. J. Transp. Res. Board 2012, 2285, 1-7. [CrossRef]

37. Meegoda, J.N.; Juliano, T.M.; Wadhawan, S. Estimation of the Remaining Service Life of Culverts. In Proceedings of the 87th Annual Meeting of the Transportation Research Board of the National Academies, Washington, DC, USA, 13-17 January 2008; Available online: https:/ / trid.trb.org/view/848077 (accessed on 20 February 2021).

38. Najafi, M.; Salem, S.; Bhattachar, D.; Salman, B.; Patil, R. An asset management approach for drainage infrastructure and culverts. Project 06-08. June 2008. Available online: https://books.google.gr/books?hl=el\&lr=\&id=hg86AQAAMAAJ\&oi=fnd\&pg= PR19\&dq=culvert + maintenance+programme\&ots=66KC38zfQI\&sig=Tj1RFfMv5Eek4SQuLaUJV1RhpmM\&redir_esc=y\#v= onepage\& $\mathrm{q}=$ culvert $\% 20$ maintenance $\% 20$ programme $\& \mathrm{f}=$ false (accessed on 20 January 2021).

39. Stergiadou, A. Environmental impact assessment (EIA) for the evaluation of forest roads in mountainous conditions (Case study: Valia Kalda). Manag. Dev. Mt. Isl. Areas 2006, 2, 125-129.

40. Mavraki, C.; Arabatzis, G.; Kantartzis, A.; Malesios, C. Fostering regional development in eastern Macedonia and Thrace, Greece, through road transport projects. Econ. Anal. Policy 2020, 65, 56-67. [CrossRef] 